\title{
The Transformation of Teaching Habits in Relation to the Introduction of Grading and National Testing in Science Education in Sweden
}

\author{
Malena $\operatorname{Lidar}^{1}$ (D) Eva Lundqvist ${ }^{1} \cdot$ Jim Ryder $^{2}$ • \\ Leif Östman ${ }^{1}$
}

Published online: 27 December 2017

(C) The Author(s) 2017. This article is an open access publication

\begin{abstract}
In Sweden, a new curriculum and new methods of assessment (grading of students and national tests) in science education were introduced in grade 6 in 2012/2013. We have investigated what implications these reforms have for teachers' teaching and assessment practices in order to explore the question of how teachers transform their teaching habits in relation to policy reforms. Interviews with 16 teachers teaching science in grade 6 (Y6), over 3 years after the reforms were introduced, were analysed. Building on the ideas of John Dewey, we consider teachers' talk about their everyday practice as expressions of their habits of teaching. Habits of teaching are related both to individual experiences as well as institutional traditions in and about teaching. A categorisation of educational philosophies was used to teachers' habits of teaching to a collective level and to show how habits can be transformed and developed over time in specific sociocultural contexts. The teachers were categorised as using essentialist and/or progressivist educational philosophy. In the responses to the introduction of grading and national testing, the teachers took three approaches: Their habits being reinforced, revised or unchanged in relation to the reforms. Although the responses were different, a striking similarity was that all teachers justified their responses with wanting to do what is best for students. However, how to show care for students differed, from delivering scientific knowledge in alignment with an essentialist educational philosophy, to preparing students to do well on tests, to supporting their development as individuals, which is in alignment with a progressivist educational philosophy.
\end{abstract}

Keywords Teaching habits · Policy reform · Compulsory school

Malena Lidar

malena.lidar@edu.uu.se

1 Department of Education, Uppsala University, Box 2136, SE-750 02 Uppsala, Sweden

2 School of Education, University of Leeds, Leeds LS2 9JT, UK 


\section{Introduction}

In one way or another, the launch of major school reforms requires teachers to reconsider how they teach. However, what effects reforms get depend on a wide range of factors (Ryder 2015). In recent times, compulsory school in Sweden has undergone major changes. This study focuses on the national tests in science education and the assignment of grades to students, both of which were introduced in grade 6 (Y6) in the academic year 2012/2013, along with a new curriculum. We have investigated teachers' responses to the introduction of this centralised control in science education in Y6 as well as what implications these reforms have for teachers' teaching and assessment practices in science education. Interviews with 16 teachers teaching Y6 conducted over the first 3 years after the major reforms introducing national testing and grading were used to perform the investigation.

When teachers are given new requirements in their practice, they act in relation to what they are used to and what they knew before. Building on John Dewey's (1922) work, we consider teachers' talk about their everyday practice as expressions of their habits of teaching and dispositions to act when approaching reforms. Teachers' habits of teaching are related both to individual experiences as well as institutional traditions regarding subject content and school as a practice. A categorisation of educational philosophies is used to relate a teacher's habits of teaching to a collective level, to show that teaching can be understood as habits transformed and developed over time in specific sociocultural contexts. The incorporation of reforms in a teaching practice may require a re-modelling or transformation of teaching habits in order for them to be functional in relation to new requirements. As teachers carry on with their everyday practices, they simultaneously transform their teaching habits in relation to new requirements in a continuous process. Since the content of a reform may align more or less with a teacher's habits of teaching, the transformation process of different teachers can vary greatly.

\section{Background to the Reforms}

Three parallel reforms were introduced in the years 2011-2013 in Swedish compulsory schools. First, a new curriculum, Lgr $11^{1}$ (Skolverket 2011) and associated subject plans were established and applied starting in the academic year 2011/2012. Additionally, in order to raise the quality in schools and to get better results after declining outcomes in international comparisons (e.g. TIMSS and PISA) the government introduced grades at earlier ages. From the autumn semester of 2012, grades were to be given from Y6; previously, the first year of grades was in Y8. Furthermore, national tests were introduced in more subjects and at more ages than before starting in the spring of 2013. The main aims were to support teachers in making fair, equitable assessment and to provide a basis for analyzing the extent to which the knowledge requirements were met at different levels. Additional aims for the national tests were to support teachers' work by concretising curricula and to raise student achievement (Skolverket 2013). The science subjects (biology, physics and chemistry) were among the subjects in which annual national tests were introduced in Y6. The national tests in Sweden were compulsory for all students, but within science, each student only took a test in one of the science subjects, randomly distributed. The tests could be considered high stakes since they

\footnotetext{
${ }^{1}$ Lgr 11 stands for Läroplan för grundskolan, förskoleklassen och fritidshemmet 2011 [Curriculum for the compulsory school, preschool class and the recreation centre, 2011]
} 
were used to grade students. Nevertheless, the grades in Y6 do not have any impact on students' access to further education. After 2 years of the new national testing program, a new government was elected. This government decided to make the science education national tests in Y6 voluntary for schools. After another year, the Y6 national tests in science education ended.

Sweden has historically been one of the countries in Europe that holds off the longest in giving grades in compulsory school. Over time, many countries have come to replace grades with other forms of assessment, such as oral and written assessments, performance reviews and student reports. In one sense, the reform to implement grades in Y6 moved Sweden closer to other countries in Europe, but it also moved Sweden away from a general European trend of postponing grading, which in many cases is justified by international research (Lundahl et al. 2010).

\section{The Swedish School System and the Curriculum}

The basic organisation of compulsory school in Sweden is a 9-year program, which starts at the age of 7 . The 9 years are divided into three stages, each ending with national tests. In Y3, only Swedish and mathematics are tested; in Y6, tests are given in Swedish, English and mathematics. Science subjects and social studies subjects were then added to compulsory national testing (2013-2014). In Y9, national tests are given in Swedish, mathematics, English, science and social studies. In Y6, students also get grades for the first time, which continues every semester thereafter. However, school districts group students differently, so lower secondary school may start either in Y6 or in Y7. With a focus on Y6, many schools teach Y4-Y6 with a class teacher that teaches the same students in most school subjects during all 3 years in middle school (Y4-Y6). Common is also to start lower secondary school at Y6 instead of Y7, and in those cases, the students are taught by subject specialist teachers. With a focus on science teaching, a consequence of students being taught either in a Y4-Y6 system or a Y6-Y9 system is that in Y6, students might be in rather different situations and get quite different preparation.

The content knowledge of teachers in the early school years has been highlighted in international research (e.g. Harlen 1997; Johnston \& Ahtee 2006). A recurring theme is that the teachers who teach younger students often have more limited knowledge of science and low self-esteem when it comes to teaching the science subjects; in some cases, they completely avoid teaching science (e.g. Appleton 2003). In a report of physics education in the middle years of compulsory school in Sweden, the Schools Inspectorate (Skolinspektionen 2011) found that the teaching of physics was more or less absent in many classrooms. It was common that the subject was embedded in a cross-curricular theme, where the particular goals, knowledge aspects and working methods of physics were used but were not made explicit and were therefore overshadowed.

In 2011, the curriculum Lgr11 replaced the 1994 curriculum Lpo94. Wahlström (2016) and Wahlström and Sundberg (2015) suggest that the differences between these curricula, in terms of concept of knowledge and competencies, can be understood by using Bernstein's competence and performance model. Lpo94 was introduced as the first Swedish national curriculum, with a model of management based on objectives and results. Results were of interest in relation to the goals that the students should achieve, and this focus was combined with a competence-based view of knowledge (Wahlström \& Sundberg 2015). The Swedish curriculum reform of 2011 was in some ways an extension of the former curriculum, but it also 
dictates in more detail what should be taught in terms of core content, and it specifies knowledge requirements for every subject. Even though the two curricula have a lot in common, there was a shift from a competence-focused curriculum in 1994 to a more explicit focus on control and result in the curriculum of 2011 (cf. Sundberg \& Wahlström 2012). Wahlström (2016) shows that concerning the policy underlying Lgr 11, Sweden converges with the European transnational discourse of what counts as knowledge in the conceptualisation of basic skills and standards. On the other hand, in relation to transversal skills, the Swedish curriculum rather diverges from transnational policy documents, because of its emphasis on separate school subjects.

In the present subject plans for each of the science subjects in Lgr11, there are detailed statements of aims, which include presentations of three competencies that concern communication, investigative study and the understanding of concepts. These are followed by presentations of the knowledge to be taught in the form of core content and statements of knowledge requirements. The national tests were formed in three parts which each took their departure in one competence. A selection of core content was used, and how to assess was described in an assessment instruction, since it was the school's responsibility to mark the tests.

An analysis and comparison between the Swedish curricula and the national test items displays that the content of the tests corresponds well to the goals and knowledge requirements stated in the curriculum (Almqvist \& Orpwood 2014). However, it is also shown that the tests do not succeed in assessing all competencies with the same reliability and validity. This becomes evident in the assessment of scientific inquiry and goals associated to socioscientific issues, where for example the use of paper-and-pencil tests is a constraint in promoting validity.

We can conclude that there have been changes in the curriculum both in terms of control and in terms of views of knowledge and that teachers encounter the reforms with different educational background and experiences. Therefore, we find it important to explore what implications these reforms have and to gain further knowledge about how teachers transform their teaching practices in relation to reforms.

\section{Educational Change - Consequences in Teaching Practices from Using Standardised Testing and Grading}

Fullan (1993) discusses how educational change creates a disequilibrium which can be uncomfortable for the participants (i.e. teachers and students). He argues that reform processes must make sense for those who it concern, both on an internal and external level. Fullan (2010) proposes four drivers that are crucial elements in a sustainable reform: intrinsic motivation, instructional improvement, teamwork and allness. He states that a key issue is to situate the energy of teachers and students as the central driving force, aligning the purpose of the reform with what is motivating and functional for the participants. In terms of teaching, the consequences of not taking teacher autonomy into consideration are illustrated in a study about environmental education, where Cotton (2006) found that teachers did not implement the curriculum the way the curriculum developers intended. Since the new curriculum was radically different and not in line with most teachers' beliefs about appropriate content, these teachers had difficulties accepting and implementing the reform. Wallace and Priestley (2011) found that when teachers were given the opportunity to create their own reform methods, this became a significant factor for promoting the reform policy. These studies signal that it is vital 
to provide teachers with a degree of autonomy in order for them to find the curriculum reform useful.

Standardised tests can be claimed to provide a discursive control that defines the acceptable pedagogic identities of teachers and also create norms about what counts as valid content and valid methods in teaching (e.g. Au 2009). In a US context, Au (2011) describes the development of the school system as being regulated by efficiency improvements, such as standardised tests, that govern the details and reduce the professionals' opportunities for selecting and reflecting on content. Worldwide, testing continues to increase, even though research on the effects of high-stakes tests does not necessarily show improved student learning outcomes (Anderson 2012).

Overall, national tests affect teachers' instruction and students' learning, though there seems to be great variation in what the effects are (e.g. Anderson 2012; Barnes et al. 2000). A common reaction to state/nation standards and tests is that the content of teaching is adapted to what is tested (Au 2007; Hamilton and Berends 2006). In a meta-analysis of 49 American studies, Au (2007) found that the main effect these types of tests have is that educational content is limited to what is tested, the subjects are fragmented into test-related pieces, and teachers increase their use of teacher-centred pedagogy. In the same vein, Anderson (2012) found in his research review that science instruction often was narrowed because of the pressure for accountability and that teachers' teaching practices became more fact-based. Another consequence was that teachers became less satisfied with their teaching and that many students' needs were not met. Collins et al.'s (2010) show that the use of standardised tests limits the teaching content, and students in some schools in Y6 did not have opportunities to engage in, for example, exploratory activities, field trips or drama, activities that could be possible alternative routes to reaching curriculum goals. To meet the objectives, preparation for testing was undertaken, which did not leave as much time for investigative activities. However, this picture of the national tests is not one-sided. Au (2007) also found the opposite picture in a significant minority of the cases of standardised testing, where the teaching content was actually expanded, knowledge was integrated, and more student-oriented teaching was used. Au's results show that depending on how the tests are designed, they can have different effects on teaching practice.

Plank and Condliffe (2013) state that the implicit logic behind high-stake tests and performance measures, with teachers and schools held accountable for the results, is that it will make teachers align their teaching to the standards and adjust their teaching practices so that all children succeed on the assessments. However, the conclusion from this study was that there is an inverse relationship between accountability pressure and classroom quality. Classroom quality was lower when classrooms were under higher pressure to increase student performance on tests. Pope et al. (2009) show that consequences from accountability measures, in the form of demands for high scores on tests, result in teachers teaching to the tests, which then can have implications for the reliability of the results from the tests. Their study shows that teachers sometimes end up in difficult situations when a student's result on a standardised test does not reflect the student's grade and causes the teacher ethical dilemmas.

The relationship between standardised testing and grading is well examined (e.g. Black et al. 2010; Tierney et al. 2011). This research points out that grading has become regulated to a large extent and that teachers need to refer to standards of different kinds. However, the question about grading and effects on teachers' instruction does not seem to be a central question in international research on education, though some researchers have begun this investigation. For example, Wahlström and Sundberg (2015) show that a large proportion of 
Swedish teachers claim to be more thorough in their assessment of student learning after the introduction of grading.

Given this background, there is reason to think that the introduction of national tests and grades can change teaching and assessment practices and also teachers' perceptions of what counts as good science instruction. However, it is not certain that all teachers' instruction is affected in the same way. In Coburn's (2004) study, teachers were more likely to engage with new ideas if they could connect them with their preexisting ideas. Outlining teachers' different responses to science education reform, Ryder (2015) found that there is a need to pay more attention to teachers' experiences and reflection over time and to make visible the process of adapting a reform to local context. In line with this observation, the present study can contribute with knowledge about teachers' enactments of a reform over time, using the concept of teaching habits as a tool to analyse and understand the tensions concerning continuity and change in teachers' transformations of the reform.

\section{Habits and Educational Philosophies in Teaching Practices}

Dewey's pragmatist notion of habits is used in this study to help create understanding about if and how teachers respond in different ways to the same reform. A key stance in the pragmatist understanding of the concept of habits is that habits weave together cognition, emotion and action (Garrison 2002), which makes the concept useful in understanding the complex situations where teachers work. A common approach to studying teachers' meaning-making and knowing as well as their responses to reform is to study teachers' beliefs or views of a phenomenon (e.g. Coenders et al. 2008; Cotton 2006; Wallace \& Priestley 2011). Beliefs are said to form the core of what a teacher thinks and direct how classroom action is performed (Lumpe et al. 2000). Wallace and Priestley (2011) point out that teachers tend to enact reforms in relation to their own beliefs. Whilst the definitions of teachers' beliefs are not entirely uniform, a common characterisation is that beliefs are "the cognitive structures that teachers bring to bear on classroom decision-making" (Wallace \& Priestley 2011, p. 360). Instead of aiming to explain teachers' individual beliefs or knowledge as something that lies behind the responses to reforms, we approach teachers' responses as related to the habits of teaching the teachers are using in their everyday practices, which become visible in how they talk about their everyday teaching practice. This approach has previously been used in analyses of teacher interviews, for example, by Sund (2016). This is a way of reflecting on teachers' actions in order to understand how teachers approach reforms in their everyday science teaching. In this view, responses to reforms are not seen as individual phenomena, like cognitive structures, but as patterns in ways of teaching that are shared by teachers in different times and places.

In Human Nature and Conduct, Dewey (1922) describes human action as not always deliberate or planned but, rather, based on habits. Dewey envisioned habits as biological functions, like breathing or digestion, and as such, they have tremendous impact on our will, our capacities, our perception and other important realms. Dewey emphasises that "[r]epetition is in no sense the essence of habit" (Dewey 1922, p. 42). In this way, the use of the word habit may seem to be twisted from its ordinary use, but he elaborates:

[...] we need a word to express that kind of human activity which is influenced by prior activity and in that sense acquired; which contains within itself a certain ordering or 
systematization of minor elements of action; which is projective, dynamic in quality, ready for overt manifestation; and which is operative in some subdued subordinate form even when not obviously dominating activity. (Dewey 1922, p. 31)

Consequently, teachers develop personal habits of acting on the basis of being educated in, being in and working in contextual situations created by earlier generations of teachers and traditions within their disciplines. Habits are thus acquired and are alterable depending on the circumstances. The concept of habits can be used to describe individuals' predispositions for certain responses to situations and problems that arise within a specific sociocultural context (cf. Nelsen 2014).

Tensions may emerge when a teacher's habit does not correspond with how he or she perceives the new requirements of a reform. Whilst habits are stable and not liable to change, when our encounters with the world come into conflict with our habits, this clash requires a transformation that may result in modifications of customs and conventions (Dewey 1922, p. 62). Dewey presents "intelligent habits" as ideal, where the habits are plastic and adaptable to new situations whilst retaining their usefulness. When faced with changes in the environment or new requirements in a context, individuals tend to first see to what is possible to keep and how the changes align with existing individual habits. In this study, intelligent habits are shaped in teachers' transformations of teaching habits when finding functional ways of acting in relation to personal convictions, disciplinary and institutional traditions and what they perceive is expected from them in the reforms.

Disciplinary and institutional traditions in science education have been investigated, and it is possible to identify patterns in the selection of purposes, content and methods used in teaching (e.g. Van Driel et al. 2008; Fensham 1988; Gyllenpalm et al. 2010; Roberts 2007, 2011; Östman 1995, 1996). These selections can be discerned when some things are taught, whilst others are excluded. When the selection of content and methods of teaching are made in a systematic way at different times and in different sociocultural contexts, we can say that a selective tradition has been formed (Englund 1986). Selective traditions denote the customs that are shaped over time within institutionalised educational practice. The patterns of what is included/excluded in a selective tradition are based on values: To make a choice, we must make a valuation. The selective traditions thus include different social and ideological purposes as well as different values and approaches (e.g. epistemological). Educational philosophy is one approach that can make visible selective traditions, and we will use it as a tool to analyse habits in teachers' descriptions of their teaching.

The educational philosophy spectrum has been mapped in order to show different ideals at different times in teaching and the tensions between them (Englund 1986; Östman 1995). These ideals concern both the purpose of education (e.g. whether the school should pass on cultural heritage or if it should be aimed at preparing for a future society) and what activities should dominate work in schools (e.g. disseminating knowledge and individual learning or starting from the student's perspective and encouraging collaboration). Östman (1995) applied the educational philosophy spectrum to the Swedish science education field and found that three educational philosophies have been used in textbooks and curriculum material between 1960 and 1990: essentialist, progressivist and reconstructivist. In an essentialist educational philosophy, the school should present the students with scientific truths and correct explanations. Science subjects in schools can be said to be constructed to be simplified versions of the academic disciplines, and the teaching of a school subject includes making the teacher responsible for introducing the students to the essential concepts, theories, methods and ways of reasoning in the subject. In the 
progressivist educational philosophy, the student is seen as someone who is active in making his or her own experiences. Teaching should take its departure in the students' experiences of the world, which means that the boundaries between different school subjects are not important. Cooperation and social consciousness is important in education, together with students' own inquiries of the world. In the reconstructivist educational philosophy, emphasis is on the content of teaching as it relates to the students' future roles as citizens. It is recognised that education always includes values of different kinds, but this philosophy brings into question which values are valid. Democracy is nevertheless an irrefutable value in reconstructivist educational philosophy, and teaching must start with an aim of democracy, rather than taking its departure point as the academic disciplines.

We view teachers' actions and talk about their everyday work, in our case including the enactment of reforms, as habitual ways of acting. Educational philosophies are used to understand that teachers do not act in a vacuum but from habits which constitute dispositions to act.

\section{Purpose}

The overarching aim of this study is to investigate teachers' responses to the introduction of increased centralised control in science education in the form of grades and national testing.

The point of departure is the premise that depending on teachers' habits of teaching, the predispositions for responding to reforms may be different. We will investigate how teachers' habits are transformed in different ways in their everyday practices and how the responses can be understood in relation to their predispositions to act.

Changes in well-established practices do not happen instantly. The data collection for the present study consists of three rounds of interviews for three consecutive years. To examine the purpose, taking into account the likelihood of habits being both relatively stable whilst also simultaneously subject to influence with new input over the years, our research question is the following:

How do teachers transform their teaching habits in relation to policy reforms?

\section{Methodology}

Sixteen teachers were interviewed, using semi-structured interview protocols (Kvale and Brinkmann 2015). Interviews were conducted three times during three consecutive years, 2013-2015, starting from the introduction of grading and national tests. In the following, we describe the process of data gathering and data analysis.

\section{Participants}

The basic criterion for the selection of teachers was that they taught Y6 science the first year that grades and national tests were given. In addition, a purposive sampling was made in order to ensure a broad variation in teaching experience, educational background and school settings (i.e. different geographical areas, school sizes and governance ${ }^{2}$ ). All teachers in the sample

\footnotetext{
${ }^{2}$ All compulsory schools in Sweden are government funded, but the governance form can be either public or independent. 
teach $\mathrm{Y} 6,{ }^{3}$ but the informants can be divided into two groups: teachers who also teach multiple subjects in lower grades (class teachers) and teachers who also teach higher grades (subject specialist teachers). In order to recruit teachers, principals of schools in different areas and run by different public and private institutions were contacted by telephone. We introduced the project and requested to get in contact with teachers that may be willing to participate in an interview. By way of the principals, we got in touch with Y6 teachers who agreed to participate. They were informed about the conditions for their participation and assured that they could withdraw their participation at any time. Unfortunately, some of the teachers dropped out in the second ${ }^{4}$ and third ${ }^{5}$ round of interviews due to retirement and sick leave. When the project started, the teachers in our sample had been teaching between 2 and 45 years and were all well established in their schools. A majority of the respondents are women, but since there are about three times as many women as men in the science teaching staff in compulsory school (Skolverket 2016), it is a reasonable selection. An overview of teacher characteristics can be found in Table 1 .

\section{Data Collection}

The interviews were conducted by the first and second author, primarily at the respective schools, but on a few occasions, teachers wanted to come to our university facilities, and a few interviews were conducted over the phone. The second interview was conducted in pairs when possible, since we saw an advantage in allowing the teachers to address other teachers' opinions and positions. In total, the analysis is built on 44 interviews that lasted between 36 and $63 \mathrm{~min}$.

Using semi-structured interviews, we had a set of themes we intended to touch upon in each interview, but the questions were coordinated to the individual teacher, his/her situation and to the responses given. The purpose of the first interview, as presented to the participating teachers, was to get an initial picture of what content and to what extent science has been taught up until now, to get their views of science and science education and also to get their responses to the reforms. The teachers were asked to present their backgrounds in terms of education and former work as well as to describe their schools and how the teaching of science was organised, both in terms of form and content, particularly in Y6. They were asked how they perceived their teaching in relation to the reforms, if they thought they would or had changed their teaching in response to the reforms and if so or if not, what the reasons were. In the second interview, we repeated the questions on the teachers' views on science and science education, but the main focus was on the content of the national tests and the relationship of these tests to grading practices. The teachers were asked to give examples of questions they thought were especially good and give arguments for their opinions. Also in this interview, they were asked to reflect on how they were influenced by the reforms. In between the second and third interview, the national tests in science became voluntary. Each school got to decide whether they would administer the test or not. Consequently, in the third interview, the teachers got to answer questions about their opinions about the current situation: their thoughts on the tests being voluntary, how the tests and grading had affected their teaching practices so far and

\footnotetext{
${ }^{3}$ Commonly in Swedish schools, teachers teach the same students during all their years at a certain stage, i.e. a teacher would teach the same students throughout grades $4-6$ or 6-9.

${ }^{4}$ T2B did not take part in interview round 2.

${ }^{5} \mathrm{~T} 1 \mathrm{~B}, \mathrm{~T} 8 \mathrm{~A}$ and $\mathrm{T} 10$ did not take part in interview round 3.
} 
Table 1 Details of teachers and schools involved in the study. The number in the labels of the teachers refers to a school; A and B means that there are some teachers teaching at the same school

\begin{tabular}{lllll}
\hline Teacher & Gender & Teaching experience & Employment & School size and environment \\
\hline T1A & M & 35 years & Subject teacher (Y6-Y9) & Medium, rural \\
T1B & F & 18 years & Subject teacher (Y6-Y9) & \\
T2A & F & 3 years & Subject teacher (Y6-Y9) & Large, suburb \\
T2B & F & 13 years & Subject teacher (Y6-Y9) & \\
T3A & F & 15 years & Subject teacher (Y6-Y9) & Large, small town \\
T3B & F & 6 years & Subject teacher (Y6-Y9) & \\
T4 & F & 12 years & Subject teacher (Y6-Y9) & Medium, rural \\
T5A & F & 2 years & Subject teacher (Y6-Y9) & Large, inner city \\
T5B & F & 18 years & Subject teacher (Y3-Y9) & \\
T6 & F & 13 years & Class teacher (Y4-Y6) & Medium, suburb \\
T7 & F & 14 years & Class teacher (Y4-Y6) & Small, suburb \\
T8A & F & 45 years & Class teacher (Y4-Y6) & Large, inner city \\
T8B & F & 12 years & Subject teacher (Y6-Y9) & \\
T9 & F & 30 years & Class teacher (Y4-Y6) & Small, rural \\
T10 & F & 20 years & Class teacher (Y4-Y6) & Medium, small town \\
T11 & M & 33 years & Class teacher (Y4-Y6) & Small, small town \\
\hline
\end{tabular}

their thoughts about the future. The questions were asked against the backdrop of the teachers' views on science and science education.

All interviews were audio-recorded and transcribed verbatim. They were conducted in Swedish and translations from Swedish to English were done word for word, but with the aim of making the spoken language understandable and believable in English. The excerpts used in the paper have been carefully edited for readability.

\section{Data Analysis}

The analysis process started out with all authors thoroughly reading the interviews from the first interview round. In this first reading, our broad focus was on what the teachers recognised as affordances and challenges in science teaching in relation to personal goals, content and assessment practices when working with the reforms. The analysis was done in connection to their descriptions of how they engage in teaching in everyday practice, in other words, their habits of teaching.

Using the different affordances and challenges that were noted as a starting point, we read the interviews from the remaining two rounds to investigate if these positions lingered or changed along the way. By interviewing teachers over time, we could track changes in their ways of talking about their teaching in relation to the reforms. The remarks and statements were systematised for each teacher in order to answer questions about teachers' habits in teaching science and how the teachers responded to the reforms in relation to their habits. We also categorised each teacher regarding what he or she saw as the overriding purposes of learning science and connected this to educational philosophies.

The categorisation of teachers was preceded by in-depth discussions of the teacher responses in relation to the theoretical categories. Thereafter, the first and second author each suggested a categorisation, and the mapping was compared and the differences discussed. With some adjustments, we could agree on the categorisations. 


\section{Results}

In the teachers' responses, there is a range of different ways of approaching the reforms, but there are also some aspects of the reforms that the teachers have responded to in similar ways. A common response from the teachers concerning the national tests includes seeing them as a confirmation of their own teaching being in line with what is required. Many of the teachers also find the tests instructive for new ways of teaching. They talk about them as helpful in finding the right level in assessment and in giving examples of how to interpret the subject plans and knowledge requirements. Grading in Y6 is a concern for most of the teachers, and the new practice of grading students in $\mathrm{Y} 6$ also has consequences for teaching. Grading requires teachers to be more transparent in teaching and assessment and thus has to be an obvious part already when planning for teaching. Many of the teachers say they find it hard to grade students, but habits of assessing students are challenged in different ways depending on for example their experiences of and approach to grading.

Although we found similarities in responses, when analyzing the teachers' valuation of grading and national testing, and how they describe their actions in relation to this, we found that the teachers in a broad sense took three different approaches: (1) Their engagement in science and science teaching was considered to be in line with the reforms and to strengthen their positions on what science teaching and assessment ought to be about. In other words, their teaching habits were reinforced in relation to reforms; (2) they considered their science teaching not to be completely in line with what they considered to be valued in the reforms and therefore needed to revise their teaching habits (i.e. what they valued as important); and (3) they considered their science teaching to be satisfactory in relation to their own valuations of teaching, science and the curriculum, and thus, their teaching habits were unchanged. When combining the approaches to reforms with an analysis of each teacher's alignment to educational philosophies, the following picture emerged (Fig. 1):

We chose to place the teachers in a gradient of positions instead of in fixed categories. Labelling the teachers within fixed categories runs the risk of forcing them to fit into existing patterns and providing a narrow picture of teaching practice. In this two-dimensional picture, we would overlook nuances of what it means to work with reforms in action. In Fig. 1, the subject teachers tend to be placed to the left in the figure, aligning with essentialist educational philosophy, whilst it is more common for the class teachers to be placed in the middle, aligning with the progressivist educational philosophy. Notably, we did not assign any of the teachers to a reconstructivist educational philosophy.

To be able to show the complexity of teaching practice in working with reforms, we will in the following present the analysis of the transformation processes of three of the teachers (T2A, T6 and T9) in a close-up narrative. The narratives of these three teachers were selected because they demonstrate contrasting positions in Fig. 1. In the three narratives, characteristic features in terms of what is valued in teaching and assessment and in approaches to the reforms are shown, along with a demonstration of the diversity and richness in different positions.

\section{The Narratives of Three Teachers}

The presentation of three teachers' narratives makes visible how these teachers find that their teaching, starting from functional, habitual ways of teaching, has been affected by the reform in the selection of content, methods and ways of assessing and how these aspects have been reinforced, revised or have remained unchanged over time. 


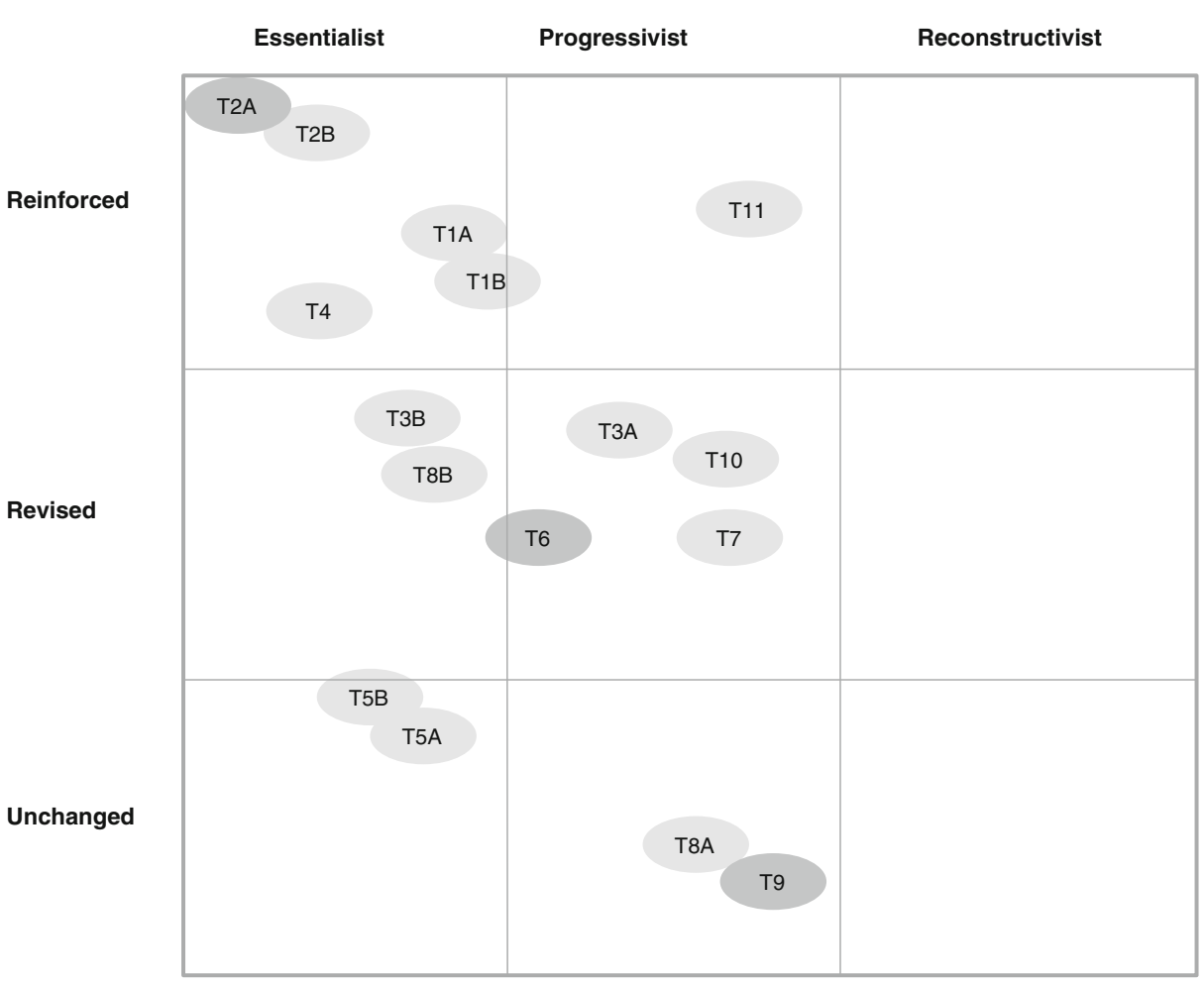

Fig. 1 The categorisation of approaches to grading and national testing combined with educational philosophy

\section{Teaching Habits Reinforced in Relation to Reforms-T2A}

The overarching goal of science education in this teacher's practice when teaching grades 6 to 9 is to get students interested, involved and engaged in science. The teacher stresses that science is in everything around us and that science can help us to better understand our world, nature and how everything works. This teacher has a strong subject focus and talks a lot about how important it is to know about science and to understand its processes. To understand science is to get a new view of the world. She says,

Everyday life will be much easier when you understand the background, and the background is the natural sciences. (T2A, first interview)

She describes central characteristics in her science teaching as inviting students to contribute to the lesson and practical work. She involves the students by asking questions at the beginning of a teaching unit or a lesson in order to get the students interested and feel that they have given some thought to the topics in the unit. L2A argues that the students get a better understanding of science by investigating. When working with investigations, students can simultaneously work with the understanding of the basic facts, the history of science and the writing of reports. She talks about how she avoids using everyday language in science class but instead encourages the students to use scientific terminology in everything they do, which indicates a habit of putting the core science content in the foreground. 
In the first interview, T2A expresses that she thinks she will change her teaching as an effect of the reforms. They have and probably will have consequences for how she plans, performs and assesses in her teaching practice. From this teacher's perspective, the national tests mean more workload, but foremost, they are support. The tests give confirmation that her teaching is in line with what is expected, and they can be a help when the students ask for reasons why science is important. She predicts that science teaching will get more serious because of the national tests, and as a consequence, the level of teaching in science in Y6 will be higher. However, in the third interview, she expresses that testing also brings disadvantages. She experienced that the tests have a negative emotional impact on the students, since they bring on a lot of stress. She has had students who simply did not show up at school on the test day because they felt it was too negative. Nevertheless, to test students' knowledge in this way corresponds well with her description of the way she works and with the demands she says are reasonable to put on students.

The tests not only confirm the teacher's approach to teaching but also the teacher's assessment of the students. The tests help the teacher to make correct and precise measurements of students' knowledge, but because the tests are now given in Y6, they can also be used for formative purposes. This teacher will teach these students from Y6 until Y9, so the teacher can use Y6 tests to understand the students' knowledge base and make use of that knowledge when planning subsequent teaching.

I think the national test is very good. Not that it can tell me what grade a student should have, but I can use it as a basis when I do a formative assessment, and it is very valuable. It is. Both from my point of view and I think from the students' point of view, even though they feel stressed, I can help them in a different way. (T2A, third interview)

In this way, the tests reinforce the teacher's habits both in the way the teacher is teaching and assessing in her practice. She considers her way of engaging in science teaching to be confirmed in the introduced reforms and thus strengthens her position on what science teaching and assessment ought to be about.

Since the introduction of the curriculum in 2011, this teacher has worked a lot with rubrics. She first paid attention to this tool when national tests in science were introduced in Y9 in 2009. Rubrics have evolved to be an important instrument in T2A's work in order to reach the curriculum goals. She uses rubrics in planning, in the actual teaching and in the assessment of students. She expresses that she "love[s] to make rubrics and cannot live without rubrics" (T2A, first interview).

The rubrics she uses are designed in the same way as they appear on the national tests, that is, in relation to the three competencies in the subject plans. She also constructs her own tests in a similar way, divided into parts that each examines one competence. For every test, there is a rubric, and she also constructs an overarching rubric for the whole teaching unit.

I sat down with a grading rubric from an earlier national test and turned it into my own from a lab that students did today, just for me to assess their work. So I can't be without them. I use them a lot to develop myself, so in this way it has helped me. It does not control me, but it allows me to evolve. (T2A, third interview)

She describes how the rubrics are a great help in concretising the content and the levels of grading for the students. In this way, the students get involved in the way of thinking, and the teaching and assessment are not two separate parts; they are intertwined. 
The teacher concludes that the reform, foremost the national test, has affected her work to a great extent:

Yes, in that I evaluate myself a lot more. I always ask the question one more time, "Did I create a fair assessment? Have I thought this through?" and it has meant that I almost always go back, read again. Look at some examples. So it has helped me to get answers to many questions that were difficult for me. Quite simply, many questions. And it has become a part of my work, a part of my assessment. So when I work with a teaching unit, I always look back. It does not control me, but it can be a tool for my teaching, and so it has helped me a lot. I use the national tests constantly, the model, as a way to assess, a way of thinking. (T2A, third interview)

T2A does not see any constraint in terms of the reform controlling her work; instead, both grading and national tests help her finding ways of performing teaching and assessing students. She finds no tensions in the enactment of reform, except that the students experience the tests as stressful. She makes the reforms align with her teaching habits, which is what she values as good teaching. In this way, the reforms create favourable conditions for continuing to work in the way she does and to strengthen and develop the clarity of assessment and thereby raise the level of teaching. The teacher's habits are thus reinforced and developed. When the tests were made voluntary in 2015, the school decided to give the tests, and T2A was pleased with that decision.

In her description of what she finds important in teaching science and her way of working with assessment, we find an essentialist approach to teaching. If we understand the strong focus on "pure" science as a predisposition for responding to the introduced reforms, it is reasonable that the part which $\mathrm{T} 2 \mathrm{~A}$ finds most confirmation in is the way to think about assessments and how the assessment of students is the best way to promote good teaching and learning.

\section{Teaching Habits Revised in Relation to Reforms-T6}

T6 expresses that the goal of science teaching where she teaches Y4-Y6 is to get as many students as possible interested in science. She says everyone needs the general knowledge, but we also need scientists to "save the world" (T6, first interview). She describes her science teaching as characterised by many discussions in the classroom, starting with the students' everyday experiences. An advantage to being a class teacher is that it gives the opportunity to have ongoing discussions.

T6 expresses that she has difficulties figuring out how to work in accordance with the new subject plans, and she struggles to find acceptable ways. In the first interview, she explains that she is primarily using textbooks for planning her teaching, but she predicts that she will increasingly use the national tests. This was confirmed in the second and third interviews. The new subject plans were not entirely in line with this teacher's teaching habits concerning what science education should include in Y6. She has noticed that, for example, systematic investigations are now important content:

I will be working a lot more with systematic investigations and practicing that, instead of just doing... Before, I did more of what I've wanted to do, some fun experiments. (T6, first interview) 
She finds, in some ways, that the students are too young to work with science in this way. Rather, they should work with discovering that science is exciting, start investigating, learn a few concepts and gain experiences to hook them on science learning. It causes internal conflict for her to balance her conviction of the importance of making science teaching fun and exciting with what she perceives the subject plans stipulate. She is doubtful that the tests will improve her teaching practice and is also worried about whether the tests will govern and change her teaching in a way that is not in line with the way she wants to teach.

In interview 3, the issue of systematic investigations is addressed again, and now, after the third round of tests, T6 has revised her habits to some extent. She talks about the testing as helping her concretise how to work with that kind of content:

I found it difficult before to get students to decide themselves on an inquiry because I could not think of what kind of things, I was thinking backwards, I constantly had a goal that I wanted them to come to [...] I thought that it was very difficult to specify a task that allowed the students to get there. But there in the tests, it was a lot of such assignments, where they put questions in other ways that made me actually think, I understood how to do it. So I have changed a lot and work a lot more like that now. (T6, third interview)

In the first interview, T6 was critical of national testing in science. She expressed that this kind of control was an assault on her profession: "I feel attacked" (T6, first interview). However, she nuances her position, stating that she does not think that her teaching will get better but that she might be more careful in her planning.

Even though she was not completely happy with the national testing, she chose to prepare the students thoroughly for the tests. The two science teachers at the school composed preparation materials for the students to work with:

Yes, it's because I want them to be successful on the national tests. But there I end up with a conflict of interest, because I do not think it is very interesting. [...] I have to adapt a little bit to what the tests look like, so I try to cover everything so students have a chance to succeed. So that it's not because of me that they don't pass the test, because I have not taught them, or not taught them in the right way. (T6, first interview)

After the first round, she gradually began to use the tests as a tool in interpreting and working with the new subject plans. In the second and third interview, T6 notes that she actually changed her teaching a lot and will start teaching differently from Y4.

When T6 learned that the tests were made optional, she was ambivalent about this decision. Her school chose not to give the tests, and she felt unsure about it because the tests had both good and bad results. In the third interview, she first expresses that it was very bad that they were made optional because they had been important for her professional development:

I think it was a really good implementation in the curriculum. I suddenly got it 'Yes, this is what they mean'. That is what I think you lose. And then you lose, there are some tasks that are really good, that I have reused in reworked from my mind, not taken them because they are confidential, but the idea for the tasks I have taken in order to include what [the students] are supposed to practice. (T6, third interview)

After three rounds of tests, she concludes that tests give the benefit of confirming if you have taught the right content and made a reasonable interpretation of students' achievements. It is also a good learning opportunity for teachers to be able to grade tests together with other 
colleagues, even though the assessment may still be arbitrary. However, later in the interview, she says that the tests have been too extensive and that the students are exhausted after performing all the tests. To take them away gives peace to both teachers and students.

Grading is a new practice for T6 as a class teacher. She has not graded students before, and she did not have any formal training in grading in her teacher education. Some teachers at the school have received training from the National Agency of Education, but T6 did not, and she expresses that she thinks that grading is hard. An advantage with grading is that she thinks that she will be more careful in her methods of assessing students. The assessment, with the grading criteria at hand, must be considered as far back as the planning of a teaching sequence. However, her overall view is that "I don't think you need grades in Y6 at all in science" (T6, second interview). Pass or not pass would be enough, because it is hard to grade, it easily becomes arbitrary, and the students are so different in maturity.

This teacher's habits have been transformed and revised whilst she struggled to make the reform align with her teaching practice.

T6 is ambivalent to the reforms; they generally align with what she values as good and reasonable ways of teaching, but she expresses that her teaching is still not synchronised with this view. Her habits of teaching are thus revised to fit what she perceives as desirable teaching. She finds, for example, that the questions on the national test can inspire her to find new ways to teach and assess students. However, she finds a tension between what she expresses as an increased need to assess the students, at the expense of letting students just be amazed and having fun and not feeling the pressure of being assessed. Whilst she finds the national tests helpful, they also become too influential in what and how she is supposed to teach and assess. In her descriptions of what she values in science teaching, we find an emphasis on progressivist ideals, in that she wants for the students to be able to explore science phenomena by themselves to impress them, but this is mixed with an essentialist emphasis on teaching and assessing the correct scientific truths.

\section{Teaching Habits Unchanged - T9}

T9 says that it is important to learn about science in order to get an understanding of the world around us and the environment. She teaches her students from Y4 to Y6 and states that her main goal with reference to teaching younger students is to arouse curiosity and to get students interested in science. It is also important to give students scientific knowledge in order for them to be able to take a stand on various issues, such as different energy sources and sustainability. This teacher works a lot with getting the students to work together and engage in discussion. Usually, her teaching is organised in themes, often combining the different science subjects, but she also combined science, Swedish, social studies and art together. The teacher validates this thematic teaching approach by referring to, in this case, the science subject plans, where the subjects are presented separately, but the skills are similar:

[I]t's a mix of everything and to focus specifically on the different subjects, I don't know if that's what you should do? [...] The subjects are so broad, and everything is included, and if that is what [those that created the curriculum] mean because the goals, I think, they're quite similar. It is this that they should be able to investigate or they should.... it is both in chemistry, biology and physics, if you look and then I think that's it, those are the competences. (T9, first interview) 
T9 says that they work with some laboratory exercises, even though they do not have advanced laboratory equipment at the school. The students often bring stuff from home, which they use when performing experiments. However, the teacher does not think that it is a problem; instead, she sees that it is good to start on a small scale, and then, it will be more exciting for the students when they move on to secondary levels.

T9 expresses that she often consults different textbooks and teaching materials when she plans her teaching. She draws a lot from the students' own experiences and questions. This means that a lesson plan can change depending on what comes up in class. The teacher did not use the subject plans to any greater extent earlier but expresses that they are becoming increasingly more important to use.

In the first interview, this teacher expresses that even though she finds the tests to have fairly good content, she does not look positively on the effects the tests might have on both teacher colleagues and in the classroom. The teacher predicts that national tests will have an effect on what teachers take as their points of departure in their teaching. Instead of looking in textbooks and elsewhere, as they might have done before, teachers will be looking more at what the tests contain. She strongly emphasises that she does not want to believe that her teaching will be changed just because of a centrally distributed test. One concern she expresses is that teachers will forget their responsibility to think for themselves, which she thinks is a part of being professional. She also expresses that it is important for the students to realise that they are learning for their own sake, not in order to do well on a test or get good grades:

I fear that everybody will become very governed [by the test] and will focus in a completely wrong way [...] They forget to think for themselves. And then how to get kids to understand grades [...] so it doesn't become a whip, which I could imagine it might be, that they work because of that instead of working because it's fun. Working for their own sake, that's my mantra there, they do this for their own sake. (T9, first interview)

Even though she says that she knows her students' levels of knowledge, she sees a challenge in grading students without the risk of putting them down. She values the skills of being able to cooperate and to learn to have discussions, which are not things that are measured by the knowledge requirements in the subject plans.

She says she has taught Y6 students for a long time, and therefore, she knows them well. She knows she has given them the opportunity to get the knowledge and skills that are required. In the second interview, which was performed shortly after the second round of national testing, she also expressed that she feels confident that the students have passed the test:

Should I be anxious because of this kind of test? And then when you see the test.... But I think there were good questions, too. The test was broad and covered a lot of things. But I feel that way, that if I were anxious for this, then I do not believe in my own work. (T9, second interview)

The advantage she sees with centrally distributed tests, in addition to that certain questions are good, is that assessments of students get fairer when everybody performs the same test. The drawback is that students become stressed because they have too many national tests in Y6.

T9 has very few tests in her regular teaching practice. Instead, she makes the students discuss a lot and document their work. She encourages her students to document in a way "so that you understand the experiment when you read the notes in six months or so, that is how 
you should do it" (T9, first interview). The students' documentation is used to report to parents about the students' achievements in teacher-parent conferences. She views the assessment of students as necessary but feels that there are better ways to assess than by assigning a student with a grade. Her habit when giving feedback on students' learning process is to have an indepth conversation with students and parents to communicate how to reach the goals.

Nevertheless, this teacher did grade her students and worried a bit that she has given them too high grades, whilst she is convinced that she has many good students. She considers it to be a problem that the scope for interpretation of the various grades is too wide.

In interview 3, T9 is still very negative about national tests and about grading students in Y6. Her school chose not to perform the national test when the schools could opt out. When asked if she misses the national test as a confirmation of whether she has given accurate grades or not, she answers: "No, no, absolutely not" (T9, third interview). She also says that it was not hard to decide whether to perform the tests or not: "Well yes, we laughed happily when [the decision about the voluntary tests] came, we have from the start thought that it was unnecessary" (T9, third interview).

This teacher does not think that the tests have had any effect to concretise the subject plans nor to better achieve subject goals among the students. She is happy with the test becoming voluntary but gives a more ambiguous answer when it comes to grading:

Yes, now we have of course become used to having... Because I was really negative about grades in Y6, when it was decided. But now.... no, I think.... yes, no. I do not think there should be grades in year six, because they are, as I said, there's such an incredible difference. What I see in year six might change so much [when they get older], or, well, it does. (T9, third interview)

Instead, she would rather see a system that worked toward equity through assessment support from the National Agency of Education or through cheap but well-written textbooks.

T9 is the teacher who expresses most concern about the reform and its implications. She disapproves of both national tests and grades across all three interviews. Her habits of teaching collide with the increasing focus on assessment, both concerning national tests and grades. She fears that she and her colleagues will look more to external demands and requirements and forget to think for themselves to determine what is best in each situation. In line with progressivist ideals, she has the habit of teaching thematically, and she often starts with the students' experiences and questions because this is a way to get students interested and motivated. Her convictions about teaching are based on what she sees as best for the students, and in her view, assessment is not what is best for students at this age.

\section{Discussion}

Teachers' enactment and reflections concerning policy reforms can be seen as a continuous process of transforming a complex network of competing factors, factors that align more or less with teachers' habits of teaching. Our analyses demonstrate the forms of transformation involved as teachers enact external policy reforms in their local school contexts. Using teaching habits and educational philosophies is an attempt to not only talk about the influence of individual beliefs when enacting reforms but to also contribute with tools to situate an individual teacher and his/her experiences in relation to historical and sociocultural traditions, and thus attempt to understand why teachers respond in different manners. 
In Fullan's (2010) terms, it is important that policies generate conditions that motivate and facilitate the work with reforms. Using Fullan's four drivers for a sustainable reform, we can see that teachers in our study have found instructional benefits of working with national tests, for example in ways to formulate questions to assess certain competences, and some teachers describes the use of rubrics as functional and helpful in everyday teaching practice. The reforms have in some schools also been a driver for more collegial work, for example when assessing and marking the national tests, which is talked about as a valuable consequence.

Nevertheless, as evident in the interviews with the teachers, the responses to policy reforms might be very different, resulting in their habits being reinforced, being revised or remaining unchanged. Previous research has demonstrated comparable typologies over teachers' responses to change. Ball et al. (2012) present eight different policy positions that a teacher can adopt in constructing responses to policy: They can act as narrators, entrepreneurs, outsiders, transactors, enthusiasts, critics and/or receivers. Notably, a teacher need not take on only one of these positions. Whilst we find that these positions easily could be consistent with the approaches the teachers in our sample took, our main focus was to connect responses to teachers' predispositions to act, which demands for another analytical framework. When investigating changing ideas about reading instruction, Coburn (2004) presents five different responses to proposed changes: rejection, decoupling, parallel structures, assimilation and adaptation. Assimilation was the most common response, followed by rejection. Interestingly, Coburn relates the responses to teachers' preexisting beliefs, their existing practices and the nature of the proposed change, which in our theoretical framing is called habits of teaching. We recognise similarities between Coburn's typology and our responses. With the ambition to weave together cognition with emotion and action (cf. Garrison 2002) in relation to reform, we find that concept of habits works as to not limit the analytic focus to changes in cognitive structures. Also, the use of educational philosophies identified in previous research (Englund 1986, Östman 1995) is a way of connecting research on teaching traditions to present-day teaching practice (Lidar, Karlberg, Almqvist \& Lundqvist 2017). This is an attempt to highlight that teachers are not acting independently from their environment but in an institutional and sociocultural context. With this approach, we can get knowledge about teachers' responses to reforms, and maybe by extension predict them, as related to their alignment to a certain teaching tradition. Having interviewed teachers three times during a period of 3 years, we do get a picture of what is privileged in each teacher's reasoning about their practice, and we can see that teachers are consistent in their reasoning. However, it is too simplified to say that a teacher is always acting in alignment with a teaching tradition. When planning this study, one interesting factor was that Y6 students are taught by teachers with different educational and professional backgrounds; they are trained and work either as class teachers or subject specialist teachers. In Fig. 1, we can see that the class teachers to a greater extent are placed in the middle in the figure, and subject specialist teachers are placed to the left, with a few exceptions. However, based on the sample of 16 teachers, we will not claim that educational philosophies are a general predictor of actions and reflections. Teaching is a complex practice, and teachers may include perspectives on methods and content related to different traditions, depending on, for example, what subject is at stake or the group of students they are teaching at the moment.

Östman's (1995) conclusion from a study concerning educational philosophies in teaching materials and curricula shows that the most common educational philosophy in Swedish compulsory school is a mix of essentialism and progressivism, called progressentialism, and it has also been shown how progressentialism can be manifested in teaching practice (Lundqvist, Almqvist \& 
Östman 2012). The combination of the two educational philosophies shows that there are traces from different traditions included in teaching and that teachers need to involve a wide range of content in teaching. As shown in Fig. 1, most of the teachers in our sample are positioned between the essentialist approach and the progressivist approach. In the three narratives, T6 is the one that most clearly shows a progressentialist approach, but there is also evidence of progressentialism in T2A's approach, in the way she talks about the importance students' own investigations. Similarly, the fact that no teacher was categorised in alignment with the reconstructivist educational philosophy does not mean that no such ideas were addressed in the interviews; there was evidence on occasions, but these ideas were not talked about as central in teaching.

Whilst approaches to teaching differ, one striking similarity between all of the teachers in our sample is their care for their students in relation to their valuation of what is important in teaching. Aikenhead (2006) has pointed out that teachers' highest priority certainly is to do what is right for the students. The focus on the students' well-being and success in school is central for all teachers, but, interestingly, the arguments for how to provide conditions for wellbeing are different. In T2A's three interviews, with her predominantly essentialist view, the science subjects are the central core in her teaching. The teaching of concepts and theories of science increases the learning, and gaining knowledge in science is the key to success. She express that the national tests raise the subjects' status, and the grading of students makes the students more motivated. To make science education even more serious and important is a way for this teacher to show that she cares for her students.

T6 struggles to select and arrange the subject content in suitable ways to help each student learn successfully and pass the tests. She uses progressivist ideas in her arguments about how to teach science and incorporate testing and grading as advocating an essentialist philosophy, at least initially. Much of this teacher's concern for the students is that she wants them to perform well on the test, which is a similar way of acting as reported by Plank and Condliffe (2013). To teach in accordance with the tests and prepare the students for performing well on them is this teacher's way of caring for her students. In the first year, she seeks external guidance in her work, but over the years, she becomes more familiar with the guidelines and how to interpret them. With the revision of her teaching habits, she can incorporate ideas from the tests without compromising her ideals.

For T9, on the other hand, the students' well-being is connected to the student and his or her possibility to develop as an individual, where the development should be driven by his or her own interests and curiosity. This is shown, for example, in terms of teaching the science subjects holistically and letting the students' questions guide the teaching. The focus on starting from the students' questions and activities is in line with a progressivist approach to teaching. Her care for the students is shown in not having too many written exams, which she says puts a lot of pressure on the students. Instead, she believes that assessing students can be done whilst they are working, by looking at their working process.

\section{Conclusion}

At times, external policies support the teachers' habits, and at other times, external policies can work against teachers' habits. Furthermore, the teachers in this study were often working to find a balance between accountability to the external reform of assessment and local autonomy over their classroom practices. These kinds of transformation processes are shown to have significant impact on teachers' sense of professionalism. In one way or another, all teachers in our sample express that the reforms impact on their profession. We find different reactions 
when saying that national tests and grading strengthen science teachers' profession, to the extent that one teacher feels attacked because someone else supervises the professional decisions. Wallace and Priestley (2011) highlight that when teachers are invited to create their own reform methods, it was shown to be an important factor for successful implementation of reforms. One implication of these findings is to highlight the need for school policy reform to provide sufficient flexibility for teachers to adapt the reform to local contexts and individual habits, whilst retaining common reform elements. These reforms had elements of flexibility, for example, in how schools or school units in different areas arranged for marking conferences, where teachers in collegial meetings could discuss the interpretation of the assessment of specific test items or grading criteria. Such flexibly adaptive reforms (Squire et al. 2003) can promote the goals of policy makers and the professionalism of teachers.

Another important conclusion drawn from this research is that successfully implementing new reforms presupposes that teachers get time to make the reform continuous with their teaching habits. Coburn (2004) shows that the relationship between the institutional environment and classroom practice unfolds over a long period of time, and teachers' perceptions of how congruent with existing practices a proposed change was, evolved over time. A general observation from the interviews with teachers about these reforms is their experience of lacking time. That administering the national tests is a time-consuming activity is confirmed in the National Agency of Education's own evaluation of the reforms (Skolverket 2015). Time was also the primary motive for abolishing the national tests in science in Y6 (Dir 2015, p. 36). During the time this study was carried out, the national tests were compulsory for just 2 years. This is a short amount of time to revise professional habits. It takes a lot of time to learn how to work and assess with new requirements, and teachers have a lot of new information and administrative work to handle. However, it is striking that when teachers get used to working with particular materials or content, they gradually adapt and find functional ways to work. The time constraints may not be a problem when reforms are transformed into teachers' teaching habits. Instead, the reforms might even be a tool that contributes to teaching and professional development. More research about teachers' teaching habits may help policy makers and other stakeholders make more conscious choices when working with the development of new reforms.

Acknowledgements This work was supported by the Swedish Research Council under Grant UVK 2012-5769. We are greatful for the thoughtful comments on earlier drafts of this paper provided by Professor Jonas Almqvist and Professor Emeritus Graham Orpwood. We also thank the two anonymous reviewers for constructive comments.

Compliance with Ethical Standards All participating teachers in this study have been informed about the aim and methodologies of this research and how we are using the data. All have signed a consent form on their participation.

Conflict of Interest The authors declare that they have no conflict of interest.

Open Access This article is distributed under the terms of the Creative Commons Attribution 4.0 International License (http://creativecommons.org/licenses/by/4.0/), which permits unrestricted use, distribution, and reproduction in any medium, provided you give appropriate credit to the original author(s) and the source, provide a link to the Creative Commons license, and indicate if changes were made. 


\section{References}

Aikenhead, G. S. (2006). Science education for everyday life. New York: Teachers College Press.

Almqvist, J. \& Orpwood, G. (2014). Swedish national tests in year 6 science: analysis and review. Paper presented at NERA (Nordic Educational Research Association), Lillehammer, Norway, March 2014.

Anderson, K. J. B. (2012). Science education and test-based accountability: reviewing their relationship and exploring implications for future policy. Science Education, 96(1), 104-129.

Appelton, K. (2003). How do beginning primary school teachers cope with science? Research in Science Education, 33(1), 1-25.

$\mathrm{Au}, \mathrm{W}$. (2007). High-stakes testing and curricular control: a qualitative metasynthesis. Educational Researcher, $36(5), 258-267$.

$\mathrm{Au}, \mathrm{W} .(2009)$. Unequal by design. High-stakes testing and the standardization of inequality. New York and London: Routledge.

$\mathrm{Au}, \mathrm{W}$. (2011). Teaching under the new Taylorism: high-stakes testing and the standardization of the 21st century curriculum. Journal of Curriculum Studies, 43(1), 25-45.

Ball, S. J., Maguire, M., \& Braun, A. (2012). How schools do policy: policy enactments in secondary schools. London: Routledge.

Barnes, M., Clarke, D., \& Stephens, M. (2000). Assessment: the engine of systematic curricular reform? Journal of Curriculum Studies, 32(5), 623-650.

Black, P., Harrison, C., Hodgen, J., Marshall, B., \& Serret, N. (2010). Validity in teachers' summative assessments. Assessment in Education: Principles, Policy \& Practice, 17(2), 215-232.

Coburn, C. E. (2004). Beyond decoupling: rethinking the relationship between the institutional environment and the classroom. Sociology of Education, 77(3), 211-244.

Coenders, F., Terlouw, C., \& Dijsktra, S. (2008). Assessing teachers' beliefs to facilitate the transition to a new chemistry curriculum: what do the teachers want? Journal of Science Teacher Education, 19(4), 317-335.

Collins, S., Reiss, M., \& Stobart, G. (2010). What happens when high-stake testing stops? Teachers' perceptions of the impact of compulsory national testing in science of 11-year-olds in England and its abolition in Wales. Assessment in Education: Principles, Policy and Practice, 17(3), 273-286.

Cotton, D. R. E. (2006). Implementing curriculum guidance on environmental education: the importance of teachers' beliefs. Journal of Curriculum Studies, 38(1), 67-83.

Dewey, J. (1922/1983). Human nature and conduct. In J. A. Boydston (Ed.), John Dewey: The middle works, volume 14. Carbondale: Southern Illinois University Press.

Dir. (2015:36). Kommittedirektiv. Översyn av de nationella proven för grund- och gymnasieskolan. [Committee Directive. Revision of the national examinations for primary and secondary schools.] [electronic] Stockholm: Ministry of Education, Government. Available at http://www.regeringen. se/rattsdokument/kommittedirektiv/2015/04/dir.-201536/ [2017-03-10].

Englund, T. (1986). Curriculum as a political problem. Changing educational conceptions, with special reference to citizenship education. Lund: Studentlitteratur/Chartwell Bratt Uppsala Studies in Education 25.

Fensham, P. J. (1988). Familiar but different: some dilemmas and new directions in science education. In P. J. Fensham (Ed.), Development and Dilemmas in Science Education (pp. 1-26). Philadelphia: The Falmer Press.

Fullan, M. (1993). Change forces: probing the depth of educational reform. London: Falmer Press.

Fullan, M. (2010). The big ideas behind whole system reform. Education Canada, 50(3), 24-27.

Garrison, J. W. (2002). Habits as social tools in context. The Occupational Therapy Journal of Research, 22 (supplement), 11S-17S.

Gyllenpalm, J., Wickman, P.-O., \& Holmgren, S.-O. (2010). Secondary science teachers' selective traditions and examples of inquiry-oriented approaches. NorDiNa, 6(1), 44-60.

Hamilton, L. S., \& Berends, M. (2006). Instructional practices related to standards and assessments. RAND. Retrieved from http://www.rand.org/content/dam/rand/pubs/working_papers/2006/RAND_WR374.pdf.

Harlen, W. (1997). Primary teachers' understanding in science and its impact in the classroom. Research in Science Education, 27(3), 323-337.

Johnston, J., \& Ahtee, M. (2006). Comparing primary student teachers' attitudes, subject knowledge and pedagogical content knowledge needs in a physics activity. Teaching and Teacher Education, 22(4), 203512.

Kvale, S., \& Brinkmann, S. (2015). InterViews: learning the craft of qualitative research interviewing. London: Sage Publications.

Lidar, M., Karlberg, M., Almqvist, J., Östman, L. \& Lundqvist, E. (2017). Teaching traditions in science teachers' practices and the introduction of national testing. Scandinavian Journal of Educational Research. https://doi.org/10.1080/00313831.2017.1306802. 
Lumpe, A. T., Haney, J. J., \& Czerniak, C. M. (2000). Assessing teachers' beliefs about their science teaching context. Journal of Research in Science Teaching, 37(3), 275-292.

Lundahl, C., Roman, H. \& Riis, U. (2010). Tidigt ute med sena betyg - sent ute med tidiga! Svensk betygspolitik i ljuset av internationell betygsforskning och betygssättning i Europa. [Early with late rating - late with early! Swedish assessment policies in light of international assessment research in Europe.] Pedagogisk forskning $i$ Uppsala 157. Uppsala: Uppsala universitet.

Lundqvist, E., Almqvist, J. \& Östman, L. (2012). Institutional traditions in teachers' manners of teaching. Cultural studies of Science Education, 7(1), 111-127.

Nelsen, P. J. (2014). Intelligent dispositions: Dewey, habits and inquiry in teacher education. Journal of Teacher Education, 6(1), 86-97.

Östman, L. (1995). Socialisation och mening: No-utbildning som politiskt och miljömoraliska problem. [Socialization and meaning: Science education as political and environmental/moral problems] Uppsala Studies in Education, 61. Stockholm: Almqvist \& Wiksell.

Östman, L. (1996). Discourses, discursive meanings and socialization in chemistry education. Journal of Curriculum Studies, 28(1):37-55

Plank, S. B., \& Condliffe, B. F. (2013). Pressures of the season: an examination of classroom quality and highstakes accountability. American Educational Research Journal, 50(5), 1152-1182.

Pope, Green, S. K., Johnson, R. L., \& Mitchell, M. (2009). Examining ethical dilemmas in classroom assessment. Teaching and Teacher Education, 25(5), 778-782.

Roberts, D. A. (2007). Scientific literacy/science literacy. In S. K. Abell \& N. G. Lederman (Eds.), Handbook of research on science education (pp. 729-780). Mahwah, NJ: Lawrence Erlbaum.

Roberts, D. A. (2011). Competing visions of scientific literacy: the influence of a science curriculum policy image. In C. Linder, L. Östman, D. A. Roberts, P.-O. Wickman, G. Erickson, \& A. MacKinnon (Eds.), Exploring the landscape of scientific literacy (pp. 11-27). New York: Routledge.

Ryder, J. (2015). Being professional. Accountability and authority in teachers' responses to science curriculum reform. Studies in Science Education, 51(1), 87-120.

Skolinspektionen. (2011). Skolinspektionens rapport 2011:9. Fysik i mellanåren - bortgömt men inte bortglömt. Rapport om undervisningen i fysik i de mellersta skolåren. [Schools Inspectorate report 2011: 9. Physics in the middle years - hidden but not forgotten. Report on the teaching of physics in the middle school years.] Stockholm: Skolinspektionen.

Skolverket. (2011). Läroplan för grundskolan, förskoleklassen och fritidshemmet 2011 [Curriculum for the compulsory school, preschool class and the recreation centre, 2011] (Lgr11). Stockholm: Swedish National Agency of Education. National Agency of Education.

Skolverket. (2013). Nationella prov. [National tests] Retrieved Jan 122013 from http://www.skolverket. se/bedomning/nationella-prov.

Skolverket. (2015). Skolreformer i praktiken. Hur reformerna landade i grundskolans vardag 2011-2014. [School reforms in practice. How the reforms landed in the primary school practice 2011-2014] Rapport 418:2015. Skolverket: Stockholm.

Skolverket. (2016). Personal i grundskolan. [Staff in compulsory school] Retrieved Jan 122016 from http:/www.skolverket.se/statistik-och-utvardering/statistik-i-tabeller/grundskola/personal.

Sundberg, D., \& Wahlström, N. (2012). Standards-based curricula in a denationalised conception of education: the case of Sweden. European Educational Research Journal, 11(3), 342-356.

Squire, K. D., MaKinster, J. G., Barnett, M., Luehmann, A. L., \& Barab, S. L. (2003). Designed curriculum and local culture: acknowledging the primacy of classroom culture. Science Education, 87(4), 468-489.

Sund, P. (2016). Discerning selective traditions in science education: a qualitative study of teachers' responses to what is important in science teaching. Cultural Studies of Science Education, 11(2), 387-409.

Tierney, R. D., Simon, M., \& Charland, J. (2011). Being fair: teachers' interpretations of principles for standardsbased grading. The Educational Forum, 75(3), 210-227.

Van Driel, J. H., Bulte, A. M. W., \& Verloop, N. (2008). Using the curriculum emphasis concept to investigate teachers' curricular beliefs in the context of educational reform. Journal of Curriculum Studies, 40(1), 107122.

Wahlström, N. (2016). A third wave of European education policy: transnational and national conceptions of knowledge in Swedish curricula. European Educational Research Journal, 15(3), 298-313.

Wahlström, N. \& Sundberg, D. (2015). Theory-based evaluation of the curriculum Lgr11 Rapport 2015:11. IFAU.

Wallace, C., \& Priestley, M. (2011). Teacher beliefs and the mediation of curriculum innovation in Scotland: a socio-cultural perspective on professional development and change. Journal of Curriculum Studies, 43(3), $357-381$. 